\title{
An Attempt to Formulate a Preliminary Definition of the Validity of Norms ${ }^{1}$
}

\section{Introductory Findings on Norms}

The issue of validity in law has been and still is widely discussed in the literature on the subject. ${ }^{2}$ In this respect, I would like to propose a preliminary definition of the validity of norms and compare it with the conception of such a definition put forward by Leszek Nowak in the work referred to in the second footnote.

However, it will be necessary to start by making certain preliminary remarks on the understanding of norms. I assume here a linguistic approach that places norms in the linguistic sphere. Thus, I consider each norm to be an expression of a specific language. There are a number of arguments in favour of such an assumption. First of all, norms are assigned a certain meaning and the issue of ambiguity of certain norms and the relationship of synonymity between norms is considered. In semiotics, the prevailing view is that of the meaning of expressions.

1 This article is an English translation of excerpts contained in sections 1-2 of the first chapter of my work entitled Derogacja norm spowodowana nowelizacyjnq działalnościq prawodawcy. Próba eksplanacyjnego podejścia published by Wydawnictwo Naukowe UAM in 2016, to which the Publishing House has given its consent.

2 It would suffice to recall the following items from Polish theoretical and legal literature: W. Lang, Obowiqzzywanie prawa, Warszawa 1962; Z. Ziemba, Zwrot «norma $N$ obowiq̨zuje» w języku prawnym i prawniczym, „Studia Filozoficzne” 1963, no. 3-4, pp. 93-115; L. Nowak, Interpretacja prawnicza. Studium z metodologii prawoznawstwa, Warszawa 1973; J. Stelmach, Obowiq̨zywanie prawa w sensie absolutnym i relatywnym, in: Teoria prawa. Filozofia prawa. Współczesne prawo i prawoznawstwo, Toruń 1998, pp. 315-327 or A. Grabowski, Prawnicze pojęcie obowiq̨zywania prawa stanowionego. Krytyka niepozytywistycznej koncepcji prawa, Kraków 2009. 
If we agree with this dominant view, then a norm carries meaning, or it may be ambiguous or synonymous to other norms only if it belongs to a set of expressions. Moreover, although the theory of law makes a fine distinction between norms and provisions understood as sentences in a grammatical sense, this does not exclude that a certain provision may turn out to be a norm. Since sentences in the grammatical sense are expressions, and provisions are sentences in the grammatical sense, a provision may only be a norm if it (the latter) is an expression. It would be difficult to consider norms identical to provisions as expressions, and to deny other norms this qualification. Finally, the definition of truth based on the concept of fulfillment refers to sentences in a logical sense understood as expressions. Of course, norms are not sentences in a logical sense. Excluding norms from the set of expressions would determine their lack of logical value, but such a conclusion would be the result of assigning them a certain ontological status. On the other hand, a position denying norms logical value because of their content, despite having recognized them as expressions, seems to be ontologically uncommitted. Since norms are expressions, they cannot be statements understood as actions. Nor may they be the meanings of utterances, meanings of expressions or meanings of normative sentences.

At the same time, norms turn out to be complex expressions resulting from the attachment of expressions with specific content to normative operators. Since normative operators are divided into prescriptive and prohibitory only, each norm is either a prescriptive or a prohibitory one. An expression attached to a normative operator consists of a hypothesis and a direction. The hypothesis is the initial fragment of the argument of the normative operator comprising the identification of the addressee of the norm and the description of the circumstances the occurrence of which makes the norm applicable. This specification may, in particular, consist in identifying the initial moment upon which the obligation of the addressee of the norm is updated. It may also be the indication of the 
final moment after which the obligation set by the norm becomes obsolete and is no longer binding the addressee of the norm. It may also consist in identifying the beginning and the end of the period during which the addressee of the norm must act in the way it is obligated by the norm. Whereas in the direction of the norm, there is an indication of the action to be taken by the addressee, by virtue of being the object of the addressee's obligation, as long as the latter is in a situation falling within the scope of that norm. What cannot be ruled out altogether is that the direction of the norm will include a more or less precise description of how such an action should be performed. And so this will suffice for the understanding of norms.

\section{The Preliminary Definition of the Validity of Norms}

In order to provide a preliminary definition of the validity of norms, I will use the idealization method widely used in empirical sciences. ${ }^{3}$ In the approach proposed here, there are eight idealizing assumptions that make up the ideal legislator.

According to the first of them:

(Z1) $\mathrm{X}$ is the only legislator in world history.

This assumption introduces a number of simplifications. First of all, it eliminates the so-called multicentricity of the legal system arising from the fact that it is made up of laws created independently by several subjects. Moreover, it eliminates the dependence of the system in question on international law, on another concurrent legal system, or on the normative activity of various social organizations tolerated by the legislator. Finally, this assumption eliminates the influence of previous systems on the legal system in question.

3 The conception of idealization as the fundamental procedure in empirical sciences was most fully proposed by L. Nowak in his work: The Structure of Idealization, Dordrecht 1979. 
According to the second assumption:

if $\mathrm{X}$ wants to achieve a certain state of affairs, he separately orders its implementation, and if $\mathrm{X}$ wants to avoid a certain state of affairs, then he separately prohibits its implementation.

This assumption removes the extremely complicated issue of the entailment relationship between norms and the no less complex issue of instrumental subordination to norms.

Under the next assumption:

(Z3) the legal system created by $\mathrm{X}$ is shaped exclusively by enacting laws in a manner that is always, invariably, the same.

Also this assumption introduces two simplifications. Firstly, it eliminates all other factors that shape the law, apart from the law enacting process, such as precedent, custom, change in the rules of interpretation applied, change of territorial division, change in the type of State or desuetudo. Secondly - but no less importantly - this assumption eliminates those changes in the very approach to enacting laws that may have a significant impact on the shape of the legal system based on it.

According to the next assumption:

(Z4) the invariable language of $\mathrm{X}$ is a language in the sense of its logical theory.

This assumption also introduces two simplifications. First of all, the language of the legislator is to be a language in the sense in which it is understood in the logical theory of language. The language understood in this way turns out to be free of any imperfections, and thus is free of ambiguity. As a matter of fact a legislator who meets the above assumption is incapable of formulating ambiguous provisions, even if, for some reasons, he would wish to do so. Moreover, the language of the legisla- 
tor remains unchanged, which means that he will always be using the same language.

Based on the next assumption:

(Z5) the legal system created by $\mathrm{X}$ is not subject to control.

Therefore, the system is not subjected to any review, except of course to the control exercised by the legislator himself. It is also worth noting that the third of the above assumptions, by virtue of which the system created by the legislator is shaped solely by enacting, does not exclude the possibility of influencing this system by controlling actions, as the very operation of making laws may be subject to such actions.

According to the next assumption:

(Z6) the legal system created by $\mathrm{X}$ is not based on sanctions.

Therefore, none of the norms in such a system is a norm sanctioning any other norm. Of course, a system that does not contain sanctioning norms does not lose its reputation as a legal system. Nor does it mean that the norms of such a system are not binding on their addressees or that the addressees of such norms never observe them. It only means that the legislator did not entrust any specifically designated bodies with the function of administering sanctions for exceeding the norms of the system he created by addressing sanctioning norms to them, but he undertook this task himself, leaving himself free to react to information about the improper conduct of his subjects.

In accordance with the penultimate assumption:

(Z7) X enacts only one normative act.

Hence all legal solutions are contained in one normative act only. This does not prejudge its content, which, however, must be such that no additional supplementation with decisions contained in other normative acts will be needed. 
The formulation of the last assumption requires first of all the following determination of the normative construct: (1) each norm is a normative construct, (2) if A and B are normative constructs formulated in the same language, then A.B is a normative construct. As can be seen, this determination has a recursive form. According to (1), which is qualified as an initial clause, all norms are normative constructs. According to (2), which is an inductive clause, two constructs formulated in the same language and combined with a dot also constitute a normative construct. Thus, the above determination establishes the set of all normative constructs. And now, the last idealizing assumption may be formulated:

(Z8) the normative act enacted by $\mathrm{X}$ is a normative construct.

This means that the act contains only norms, and they are norms formulated in the same language. The normative act is therefore limited to the basic text only, and does not include the title of the entire text, the headings of larger editorial units, or the numbering of the provisions. A subject that meets all of the above requirements will be referred to as the ideal legislator.

After these clarifications, we can now proceed to formulating the following definition:

(D1) $\quad \wedge \mathrm{n} \wedge \mathrm{s} \wedge \mathrm{t}\{\mathrm{n}$ is valid in s created by the ideal legislator at $\mathrm{t}$ $\equiv \mathrm{Vy}$ [n is a part of $\mathrm{y} \wedge \mathrm{Vt}^{\prime}$ ( $\mathrm{t}^{\prime}$ is earlier than $\mathrm{t} \wedge \mathrm{y}$ is enacted in t' by the ideal legislator who is the creator of $\mathrm{s})]$,

where the range of variable " $\mathrm{n}$ " is a set of norms, the range of variable " $s$ " is a set of legal systems, the range of variables " $t$ " and " $t$ "” is a set of days, and the range of variable " $y$ " is a set of a subset of normative constructs in which there are no sanctioning norms. In other words, according to the above definition, a given norm is valid in a legal system created by the ideal legislator on a specific date only if it is a part of a normative act previously created by that legislator. 
As can be seen, D1 is a normal definition, in which the role of the definitional conjunction is played by the connective of equivalence derived from a sentential calculus. Since the remaining variables and constants contained in it also belong to this calculus or to the first order predicate calculus, this definition is based on the classical logical calculus. It also fulfils all the internal requirements of formal correctness imposed on such definitions. Firstly, the expression defined in it appears only in the definiendum, but not in the definiens. Secondly, each of the variables present in the definiendum appears there only once. Thirdly, all free variables in the definiens are also free variables in the definiendum. Variables " $y$ " and " $\mathrm{t}$ "” do not appear in the definiendum but they do appear in the definiens as bound variables. Since a defined expression belongs to the same language as the definition containing it, it is therefore an intralingual definition.

The first variable attached to the defined predicate is the variable " $n$ ", whose range is a set of norms. Thus, according to the definition proposed here, valid objects are norms. Therefore we cannot talk about the validity of the law, the validity of a legal system or the validity of a provision. The second variable attached to the defined predicate is the variable " $\mathrm{s}$ ", whose range is a set of legal systems. The need to attach this variable to the predicate causes this predicate to display so called relative validity i.e. the validity in a system created by a particular legislator, differing in this respect from the absolute validity that ignores this relativization. The third variable attached to the defined predicate is the variable "t", which determines the temporal relativization of validity. I assume that such a smallest temporal unit of the duration of validity is one day.

The above definition D1 indicates that, in the simplest case, the validity of a norm is determined solely by the enactment of a normative act containing it. What is more, the enacting subject is an ideal legislator and consequently the only legislator enacting just that one normative act. Therefore an ideal legislator cannot perform his function by virtue of the competence conferred on him by some other higher ranking legislator, or by virtue of the competence that he has conferred on himself earlier, 
in another normative act. Thus he may only be characterized in political terms as a subject that has power over individuals and who is therefore, using his authority, coercion or persuasion, capable of practically forcing them to respect the limitations he imposed on them. Consequently, either a single individual with extraordinary authority or a group of people strong enough to force others to respect the limitations imposed on them may be the ideal legislator. It may also be a whole community which, as a result of the mutual persuasion exercised by its members, enacts an act considered by each of them as their own. When the enacting is done by a subject that is not a legislator, no source of law is created as a result.

Since the ideal legislator has not taken over any regulations from anyone, nor has he himself issued any normative act beforehand, he is not bound by any provisions determining the course of the enacting process. The manner of enacting is determined exclusively by the culture of the community for which he is the legislator. The "enacting in the narrow sense ... in our legal culture does not require the formulation of any utterance, but is done by an act of voting by authorized subjects (in the case of a collegial legislator) or by the signing of a draft normative act by an authorized subject if the legislator is a single person." "A As can be seen, in the simplest circumstances proper for an ideal legislator, enacting boils down to the performance of one action, which is not too complicated. The legislator either performs this action, and then enacting occurs, or does not perform this action, and then no enacting takes place. Because D1 makes the validity of a norm conditional upon a non-gradual enacting process of the normative act that contains it, the validity of the norm is also non-gradual. A given norm is either valid or not valid on a specific date in the indicated legal system.

In its entirety, D1 is an expression formulated in a language that for an ideal legislator is a metalanguage. According to Z4, this language is

4 S. Wronkowska, O źródłach prawa i aktach normatywnych raz jeszcze, in: Prawo prywatne czasu przemian. Księga pamiqtkowa dedykowana Profesorowi Stanisławowi Sołtysińskiemu, ed. A. Nowicka, Poznań 2005, p. 128. 
a language in the sense of its logical theory; consequently the language of the definition in question also has this status. It is therefore made up of linguistic rules ${ }^{5}$ which are divided into syntactic rules and semantic rules. The syntactic rules are formation rules and deductive rules. The formation rules include vocabulary rules and grammatical rules, the latter covering rules that determine grammatical categories and rules that determine the way in which complex expressions are built. One of the vocabulary rules qualifies the sequence defined in D1 as a word of this language. And one of the grammatical category rules classifies this word as a triadic predicate, whereas one of the rules determining how complex expression are built allows a sentence to be built from this predicate, once three singular terms have been attached to it. In turn, deductive rules are divided into axiomatic rules and inference rules. The former include, inter alia, a rule that qualifies all definitions as theses of a given language. D1 is therefore a thesis of the language in which it is formulated, and thus is an analytical sentence in that language. As a result, definition D1 is true in every model of that language. The inference rules include a rule which qualifies as theses of this language all the logical consequences of its theses. What I also assume is that another inference rule qualifies as a thesis every equivalence of sentences that differ only insofar as that in one of them there occurs a defined expression, and in the other one - a defining expression in the definition which is already a thesis of this language.

In a language thus constituted, a definition ensures the synonymity of the expression defined in it with the expression that defines it. According to the conception assumed here, ${ }^{6}$ two sentences are synonymous in a given language when the implications created from them are theses of this language. In turn two expressions that are not sentences are synonymous in a given language when any two sentences of this language, differing solely in these expressions, are synonymous in it.

\footnotetext{
5 For more on this see J. Kmita, Wykłady z logiki i metodologii nauk, Warszawa 1973, chapters II and III.

6 V. J. Kmita, Wykłady..., pp. 59-62.
} 
While the meaning of an expression in a given language is the feature of this expression and of all and only expressions of this language that are synonymous to it.

Therefore, let us consider the phrase "«Every driver driving a vehicle on a public road must drive on the right side of the road» is valid in legal system A, created by the ideal legislator at 26 September 2020" and the sentence " $V y$ [ «Every driver driving a vehicle on a public road must drive on the right-hand side of the road»" is a part of $\mathrm{y} \wedge \mathrm{Vt}$ ' ( $\mathrm{t}$ ' is earlier than 26 September $2020 \wedge$ y is enacted in t' by the ideal legislator who created legal system A)].” The only difference between them is that in the former there is the predicate defined in D1: “...is valid in...created by the ideal legislator... at..."; while in the latter, there is the defining phrase in this definition: " $\mathrm{Vy}\left[\ldots\right.$ is a part of $\mathrm{y} \wedge \mathrm{Vt}_{\mathrm{t}}$ ' $(\mathrm{t}$ ' is earlier than $\ldots \wedge \mathrm{y}$ is enacted in t' by the ideal legislator who created...)." Because by virtue of the axiomatic rule mentioned above, D1 is the thesis of the language in question, therefore - based on the other of the inference rules mentioned above - its thesis is also the equivalence built from these sentences as its arguments. Thus the first of the mentioned inference rules qualifies both implications that logically follow from this equivalence as theses. Thus the sentences formulated above are synonymous in their language.

A legislator who meets the previously formulated idealizing assumptions is an ideal legislator thanks to the simplicity and the absence of any complications hindering the resolution of various research problems. He is not, however, the ideal legislator because he is perfect in creating the best, most effective, internal, and fully consistent legal system. The system created by the ideal legislator does not therefore preclude the validity of norms that are in various ways improper. From this point of view, the norms of the system created by the ideal legislator do not differ from those of the real legal system burdened with various shortcomings. First of all, it cannot be excluded that in the system created by the ideal legislator, there will be valid norms whose scope of application also covers situations arising prior to the enactment of the act containing them. 
Secondly, such a system does not preclude either the validity of norms which, for logical or empirical reasons, are not feasible, or the validity of norms the realization of which, for logical or empirical reasons, turns out to be necessary. There are some arguments in favour of the admissibility of the validity of such norms. First of all, this is because the legislator sometimes does enact a normative act containing such norms. What I mean here is not only the infamous instruction prohibiting passengers from getting off the plane during the flight, but also normative acts from the early post-war years imposing on individual farmers obligations to supply crops, which were impossible for the majority of them to fulfil. These obligations were so exorbitant that they exceeded the production capacity of most individual holdings. They were nevertheless enforced with all ruthlessness, and many of the farmers unable to fulfil them were sentenced to several months of imprisonment. The convictions were so determined that they could return to their field work in the spring. What is more, sometimes the legislator himself introduces provisions which eliminate obligations that cannot be met. For example, under Article $387 \S 1$ of the Civil Code, a contract that is impossible to perform is void. If, by the definition itself, a rule ordering (or prohibiting) its addressee to perform (refrain from performing) a specific act for logical or empirical reasons were to be excluded, then this rule would be superfluous. Its presence in the civil code demonstrates that the very definition does not exclude the validity of such norms.

Thirdly, in a system created by the ideal legislator, the existence of mutually incompatible or even mutually contradictory norms is not barred. If the ideal legislator included two mutually contradictory norms in an act that he enacted, both would apply in the system he has created. Due to the assumptions idealizing the legislator, the only indirect but important argument in favour of such a possibility in Poland is provided by the construction of the effects of the rulings of the Constitutional Tribunal (Trybunał Konstytucyjny) adopted in our country. This organ adjudicates on the conformity of certain normative acts 
with the Constitution and other indicated normative acts, such acts cease to be valid and binding upon the verdict of the Constitutional Tribunal coming into force. However, since until that moment a normative act challenged as unconstitutional or inconsistent with other normative acts had been the source of law, there were norms valid and binding in our legal system and covered by the act in question that were inconsistent with the norms that were also valid in that system at that time, contained in those acts.

I would also like to establish the relationship between the definition of the validity of norms proposed here to legal positivism. In its simplest form, legal positivism boils down to the thesis on the separation of law from morality. Therefore, this thesis would claim that the definition of the validity of norms does not contain a criterion that would make a norm's entry into this relationship contingent upon the fulfilment of any moral requirements. Since D1 indeed does not contain such a criterion, the conception presented here qualifies as a manifestation of legal positivism thus understood. Therefore, in the system created by the ideal legislator, the valid norms would not only be norms with scopes of application extending to situations occurring even before the enactment of a normative act containing these norms, and norms that for logical or empirical reasons are unrealizable, or norms whose realization for these very reasons is inevitable, as well as mutually incompatible norms, but also norms that are extremely improper. A system containing such norms would be immoral and therefore reprehensible, but it would not, for this very reason, cease to be a legal system.

In a slightly more complicated approach, legal positivism may be identified with a set of two theses, namely a thesis on the separation of law and morality as pointed out above, and a thesis on social facts. The latter thesis, in a stronger version, states that the enacting of the law underlying the validity of each separate norm present in a given legal system is a social fact. It is easy to note that the standpoint presented here respects this thesis in this version because according to D1 a norm is valid in a sys- 
tem created by an ideal legislator only when it is present in a normative act enacted by him. The point of view presented here also respects this thesis in its weaker version, which states that the legal system as a whole is the result of the enacting performed by a sovereign legislator. The assumptions constituting the ideal legislator include, among other things, Z3, according to which the system created by the ideal legislator is exclusively the effect of enacting, while under $\mathrm{Z} 1$ this legislator is the only one in the history of the world, which guarantees him total sovereignty in this area.

In an even more complicated approach to legal positivism, a third thesis is added to the above two ones that characterize it. It is a thesis on the social effectiveness of the law, and one that is also respected by the point of view presented here. It must also be remembered here that I refer to the political characteristics of the legislator, according to which this role may only be played by a subject with real power over his subjects, enabling him to enforce appropriate actions on them.

As can be seen, my research proposal is marked by three theses that are crucial for legal positivism. Already this is sufficient to qualify it as a fundamentally positivist conception. It therefore belongs to a trend considered by many researchers to be leading and capable of absorbing new ideas, and one on which our law, the activity of the Constitutional Tribunal and the entire legal practice is basically founded.

It should also be added that the preliminary definition of the validity of norms turns out to be relatively simple, as it is based on eight idealizing assumptions. As the assumptions are eliminated, the definition itself becomes more complicated. First of all, its definiens is expanded. Then, the entire definition is transformed into a recursive definition. These complications, however, are not the subject of my interest here.

\section{An Ideal Legislator and a Perfect Legislator}

The proposal for a preliminary definition of the validity of norms presented here is not the first to use the idealization method for this purpose. 
Many years ago such a concept was presented by Nowak in his earlier work Interpretacja prawnicza. Studium z metodologii prawoznawstwa (Legal Interpretation. Study of the methodology of jurisprudence), where he presented a number of related definitions. Now I would like to compare these two proposals, taking into account, however, only the preliminary definition he formulated. I do not hesitate to point out that the approach presented by Nowak is a model that I tried to follow here, when I presented my own point of view above. The difference in the results obtained using the same method is primarily due to the discrepancy between the intuitions we have taken into account. In making his proposal, Nowak relied on the intuitions nourished in this matter by legal dogmatics, which he was even doomed to do, since it was the first extensive treatment of the problem in the literature on the subject. My main goal is to capture the intuitions of the theorists of law connected with this issue.

When comparing the two approaches, I will focus primarily on establishing similarities and differences in the sets of idealizing assumptions. Nowak introduced as many as seventeen of them, namely: (p1) the knowledge of legislator $\mathrm{L}$ is not contradictory, (p2) the knowledge of legislator $\mathrm{L}$ is a system, that is, it covers all its own logical consequences, (p3) the knowledge of legislator L covers all the rules of the language in which the legislator formulates provisions, (p4) the knowledge of legislator $\mathrm{L}$ is the best justified knowledge from the point of view of the current state of science, (p5) legislator L's preferences are asymmetric, (p6) legislator L's preferences are transitive, (p7) legislator L's assessments determining his preferences are a full system of morally just assessments, (p8) all the provisions issued by legislator L are norms, (p9) legislator L orders people what to do only by formulating appropriate provisions, (p10) all the provisions issued by legislator $\mathrm{L}$ are practically autonomous, i.e. there is no need to issue separate implementing provisions for any of them, (p11) all the provisions issued by legislator $\mathrm{L}$ are axiologically effective, which means that achieving by means of a provision the prescribed (avoidance of the forbidden) state of affairs is the ultimate goal of legislator L, and 
is not to be only a means by which he can achieve (avoid) another state of affairs, (p12) all provisions are issued by legislator L collectively, in a single normative act, (p13) legislator L has not taken over any previous provisions, (p14) legislator $\mathrm{L}$ does not enact provisions of normative competence, (p15) the legal force of all the provisions issued by legislator $\mathrm{L}$ is equal, (p16) legislator $\mathrm{L}$ has issued all provisions in a single normative act, (p17) if legislator $\mathrm{L}$ wants to achieve a certain state of affairs, he issues a separate provision ordering its implementation. A legislator who meets all these idealizing assumptions is called the perfect legislator.

It is easy to notice that, of the above, I adopted p16 and - having formulated it in my own language - introduced it as Z7, according to which $\mathrm{X}$ enacts only one normative act. Also Z3, under which the legal system created by $\mathrm{X}$ is shaped solely by enacting carried out in the same way, may be considered to be the faithful counterpart of p9, provided that the latter assumption is correctly expressed. It must not be a matter of formulating appropriate provisions, but of enacting normative acts that consist of these provisions, because only such an operation affects the legal system. Also Z2 - which states that if X wants to achieve a specific state of affairs, he separately orders its implementation, and if $\mathrm{X}$ wants to avoid a specific state of affairs, he separately prohibits its implementation - must be regarded as the exact counterpart of p17. Contrary to what it may seem, this last assumption is not weaker than Z2, but is based on a slightly different vision of norms. Nowak considered the norms prohibiting the performance of relevant acts to be translatable into norms ordering the forbearance of such acts, and for this reason he only considered the latter. Here, however, I accept that norms are divided into norms that require certain acts to be performed and norms that prohibit certain acts, and with this division, norms of one kind cannot be easily replaced by norms of another kind. In turn, Z1, according to which $\mathrm{X}$ is the only legislator in world history, turns out to be stronger than p13. I consider this strengthening of idealization to be necessary because it allows, in the initial, simplest case scenario, the 
removal from the field of consideration the complicated problem of the dependence of the legal system not only on its previous form, but also on the neighbouring systems, as well as the norms of various internal and external organizations supported or only tolerated by the legislator. In addition, it allows one to eliminate the phenomenon of multicentricity from the legal system, which was absent at the time when the conception analyzed here was created. Also Z8, which ensures that the act enacted by $\mathrm{X}$ is a normative construct, proves to be stronger than p8. Whilst, as a result of each of these assumptions, the act enacted by the legislator covers nothing else but norms, only the first assumption ensures that all the components of the normative act are formulated in one language. Again this strengthening of idealization seems essential, as it is only owing to idealization that we may speak about the language of valid norms and, consequently, the language of a normative act containing them.

However, some of the assumptions that constitute the ideal legislator do not have their counterparts among those that characterize the perfect legislator. Namely, there is no counterpart of Z6, according to which the legal system created by $\mathrm{X}$ is not based on sanctions. This omission results from a different view of the semiotic status of decisions imposing sanctions. Sharing the opinions of many researchers, ${ }^{7}$ Nowak assumed that the decision imposing a sanction contained an individual norm. Thus, the enactment of such a norm must be authorized by a relevant norm of legislative competence. Since, under p14, the legislator does not enact provisions granting such competence, the problem of sanctioning norms also disappears. In my opinion, however, it is the authors who question the presence of an individual norm in judicial decisions, including those imposing a sanction, who are right. ${ }^{8}$ Thus a separate idealizing assumption must remove all the complications that may arise in connection with sanctions.

7 See e.g. H. Kelsen, The Pure Theory of Law, Berkeley 1970, p. 351.

8 See e.g. K. Piasecki, Wyrok pierwszej instancji w postępowaniu cywilnym, Warszawa 1981, p. 95. 
The assumptions that constitute the perfect legislator also lack the counterpart of Z4, according to which the invariable language of $\mathrm{X}$ is a language in the sense of its logical theory. I consider the absence ofa counterpart of this assumption to be a certain oversight, because a legislator who is not bound by any language limits might include in the act that he has enacted norms formulated in different languages, while only those norms for which the predicate defined here were a meta-linguistic expression would have a chance of being valid. This seems counter-intuitive. Further, among the assumptions concerning the perfect legislator, there is no counterpart of Z5, either. Z5 states that the legal system created by $\mathrm{X}$ is not subject to control, however, the absence of this counterpart is understandable, because at least in our legal system such judicial review entrusted to the Constitutional Tribunal - was introduced not so long ago.

Some of the assumptions that constitute the perfect legislator also lack their counterparts among the assumptions that characterize the ideal legislator. Primarily, it is assumptions p1-p7 idealizing the knowledge and preferences of the legislator that do not have counterparts. It should therefore be pointed out that Nowak regarded legal interpretation as a variation of humanistic interpretation. ${ }^{9}$ Since the latter is based on the assumption that the subject of the action to be interpreted is rational, assumptions idealizing the subject's initial knowledge and preferences must be made at the beginning. However, the preliminary definition of the validity of norms proposed here does not have such dependencies, hence the counterparts of the above mentioned assumptions are unnecessary.

Also p10 has no counterpart among the assumptions concerning the ideal legislator. In this case, however, the reason for this discrepancy is different. As I have already pointed out, Nowak aimed to recreate the conception of the validity of norms, which is tacitly assumed by representatives of legal dogmatics. Since their task is to improve the law comprehensively, they use such a conception of validity that allows them to

9 On this type of explanation see J. Kmita, Z metodologicznych problemów interpretacji humanistycznej, Warszawa 1971. 
perform this role as best as possible. And it is precisely the assumption that is being considered here that is part of this conception. When it is repealed, it allows, on the one hand, one to propose that the norms contained in redundant implementing provisions are not valid and, on the other hand, to propose that the norms necessary for the functioning of those norms are valid, although the relevant implementing acts have not yet been enacted. Meanwhile, my proposal is based on the intuition of the theorists of law. These scholars are not tasked with improving the law but, at most, with explaining its shortcomings. That is why I am not introducing any counterpart to this assumption here. For the same reason, I am not introducing any counterpart of p11.

Among the assumptions that characterize an ideal legislator, there is no counterpart of p12 either. Nowak emphasized that, according to this assumption, the legislator puts all provisions in collective normative acts and issues them periodically "once per one time unit (e.g. once a year)."10 I consider this assumption superfluous since, according to p16 (which has a counterpart of Z7), the legislator enacts only one normative act. For the same reasons, I do not introduce the counterpart of p15 guaranteeing the equal power of all the provisions issued by the perfect legislator. In accordance with p16 (here Z7), the legislator enacts only one normative act, and the power of the provisions in one act is always the same. Assumptions p12 and p15 could at most be used after the repeal of p16 (here Z7) as its weakening, but they should not occur simultaneously with it.

To a certain extent, the situation is similar with p14 which also has no counterpart here; p14 excludes the enacting by the perfect legislator of competence provisions. Zygmunt Ziembiński put forward the conception of competence norms comprising norms that confer legislative competence as well as non-legislative competence. ${ }^{11}$ Following this author, Nowak assumed that the power to enact laws is conferred by a particular

10 See L. Nowak, Interpretacja..., p. 56.

11 V. Z. Ziembiński, Kompetencja i norma kompetencyjna, "Ruch Prawniczy, Ekonomiczny i Socjologiczny" 1969, issue 4, pp. 23-41. 
type of norm which could therefore be present in an act enacted by a perfect legislator. To rule out this possibility, he introduced the aforementioned assumption. My attitude to the proposal put forward by Ziembiński is not so simple. ${ }^{12}$ While I consider the conception of norms conferring competences other than legislative ones to be an important research achievement, I consider the conception of norms conferring legislative competences to be unsustainable, because in this conception the legislative competence is conferred by provisions that are not norms. If that is the case, such provisions cannot exist in an act that contains only norms. Thus, the counterpart of this assumption proves to be superfluous.

Clarification of the idealizing assumptions analyzed above enabled Nowak to formulate the following definition:

(D2) if $\mathrm{L}$ is a perfect legislator 17 , then the norm !(p/A,s) is valid in legal system $\mathrm{Q}$ at time $\mathrm{t} 2$ if and only if this norm was enacted by legislator $\mathrm{L}$ at time $\mathrm{t} 1$ not later than $\mathrm{t} 2$.

In many respects, this definition differs from the one I proposed. Although the expression "valid in ...at..." as defined in D2 is also a triadic predicate that denotes the relationship between a norm, a legal system and a time period, this definition also includes relativization to the legislator. The predecessor of this definition establishes his perfection. Therefore, it is not a normal definition, but a conditional definition. What is more, the right-hand argument of the consequent of the definition, which is the counterpart of definiens, stipulates the necessary condition for the validity of the norm, which is its enactment by the legislator. This condition raises a reservation, since it is normative acts that are enacted in this way, but not individual norms. A single norm could only be enacted if it were identical to a normative act, which almost never happens. Finally, in the right-hand argument of the consequent of $\mathrm{D} 2$, there is variable ' $\mathrm{L}$ ', the range of which is a set of legislators, absent in the left-hand argument of this equivalence. This would necessitate its correction.

12 V. W. Patryas, Performatywy w prawie, Poznań 2005, pp. 79-87. 


\section{References}

Grabowski A., Prawnicze pojęcie obowiq̨zywania prawa stanowionego. Krytyka niepozytywistycznej koncepcji prawa, Kraków 2009.

Kelsen H., The Pure Theory of Law, Berkeley 1970.

Kmita J., Wykłady z logiki i metodologii nauk, Warszawa 1973.

Kmita J., Z metodologicznych problemów interpretacji humanistycznej, Warszawa 1971.

Lang W., Obowiq̨zywanie prawa, Warszawa 1962.

Nowak L., Interpretacja prawnicza. Studium z metodologii prawoznawstwa, Warszawa 1973.

Nowak L., The Structure of Idealization, Dordrecht 1979.

Patryas W., Performatywy w prawie, Poznań 2005.

Piasecki K., Wyrok pierwszej instancji w postępowaniu cywilnym, Warszawa 1981.

Stelmach J., Obowiq̨zywanie prawa w sensie absolutnym i relatywnym, in: Teoria prawa. Filozofia prawa. Współczesne prawo i prawoznawstwo, Toruń 1998.

Wronkowska S., O źródłach prawa i aktach normatywnych raz jeszcze, in: Prawo prywatne czasu przemian. Księga pamiatkowa dedykowana Profesorowi Stanisławowi Sołtysińskiemu, ed. A. Nowicka, Poznań 2005.

Ziemba Z., Zwrot «norma N obowiqzzuje» w języku prawnym i prawniczym, „Studia Filozoficzne” 1963, no. 3-4.

Ziembiński Z., Kompetencja i norma kompetencyjna, "Ruch Prawniczy, Ekonomiczny i Socjologiczny” 1969. 
SUMMARY

\section{An Attempt to Formulate a Preliminary Defnition of the Validity of Norms}

The aim of the study is to formulate a preliminary defnition of the validity of norms using idealization method for this purpose. The author proposes a preliminary definition of the validity of norms and compares it with the conception of such a definition put forward by Leszek Nowak in Interpretacja prawnicza. Studium z metodologii prawoznawstwa.

Keywords: theory of law, validity of norms, idealization method.

Wojciech Patryas, Adam Mickiewicz University Poznań, Faculty of Law and Administration, Al. Niepodległości 53, 61-714 Poznań, Republic of Poland, e-mail: wojciech.patryas@amu.edu.pl.

DOI 10.14746/ppuam.2020.11.02 
